\title{
A Study on Farm Mechanization Level of Farmers in North Karnataka, India
}

\author{
H. Shoba ${ }^{1^{*}}$, N. Rajeshwari ${ }^{2}$ and H. Yogeeshappa ${ }^{3}$ \\ ${ }^{1}$ Department of Agricultural Engineering, College of Horticulture, Munirabad University of \\ Horticultural Sciences, Bagalkot, Karnataka, India \\ ${ }^{2}$ Department of Spices, Plantation, Medicinal and Aromatic crops, College of Horticulture, \\ Munirabad University of Horticultural Sciences, Bagalkot, Karnataka, India \\ ${ }^{3}$ Department of Soil Science, College of Horticulture, Munirabad University of Horticultural \\ Sciences, Bagalkot, Karnataka, India \\ *Corresponding author
}

\section{A B S T R A C T}

\begin{tabular}{|l|}
\hline Ke y w o r d s \\
Adoption, \\
Implements, \\
Knowledge, \\
Mechanization, \\
Plough \\
\hline Article Info \\
\hline Accepted: \\
07 January 2018 \\
Available Online: \\
10 February 2018 \\
\hline \hline
\end{tabular}

Introduction

Mechanized agriculture is the process of using agricultural machinery to mechanize the work of agriculture to increase the farm production and productivity. The availability of labour to work in agriculture is becoming crucial in now a day. In Indian the population dynamics of agricultural workers shows that by 2020 will be about 230 million out of which $45 \%$ will be the female workers. It is predicted that the population in rural areas will decrease to

\begin{abstract}
A study on farm mechanization level of farmers in north Karnataka was conducted in Koppal District during 2015-16. The 150 number of respondents were selected for the study. By personal interview method the data was collected. The results showed that, 41.33 per cent of respondents had medium level of knowledge on farm implements, 30.67 per cent and 28.00 per cent of respondents had low and high level of knowledge on farm implements, respectively. More than 80 percent of the farmers were adopted sprayers $(83.33 \%)$, M.B. plough $(82.67 \%)$, more than 60 percent of the farmers were adopted Cultivators $(72.67 \%)$, Rotavators $(64 \%)$, Blade harrow $(61.33 \%)$, respectively. This was mainly due to constraints faced by framers like, drudgery involved in farm operations, scarcity of labours, it has became necessary to the farmers to adopt farm mechanization. Whereas least percentage of adoption was found in paddy transplanter $(1.33 \%)$, Hoes $(3.33 \%)$, Seed cum fertilizer drill $(6.67 \%)$, Fertilizer drill $(8 \%)$, respectively. This was mainly due to high cost and lack of awareness.
\end{abstract}

$62.83 \%$ in 2025 and to $44.83 \%$ in 2050 (Mehta et al., 2014) but to feed everincreasing population in the country there is a need to double the food production by 2020 (Sahana et al., 2017). The power requirement for seedbed preparation, cultivation and harvesting great that the existing human and animal power in the country appears to be inadequate.

Tractors, combine harvesters, threshers, rotavators, power tillers, and rice transplantors 
etc., which are huge in demand over the past few years. Farm Productivity is positively correlated with the availability of farm power coupled with efficient farm implements and their judicious utilization. Agricultural mechanization not only enables efficient utilization of various inputs such as seeds, fertilizers, plant protection chemicals and water for irrigation but also it helps in poverty alleviation by making farming an attractive enterprise. There is a need to increase the extent of mechanization to 60.00 per cent by 2020 from about 40.00 per cent now (Anonymous 2014). Koppal is an agriculture based economy with second largest produce in the state. Its major food crops are Paddy, Maize, Jowar, and Bajra and horticulture produces like Pomegranate, Grape, Banana, Mango, Brinjal, Tomato, Onion, Green Chili, Ridge-Guard and Flowers like Crossandra, Jasmine, Chrysanthemum, Rose and Marigold. The district also grows Cash crops like Groundnut and Sugarcane with Plantation crops like Betel Vine, Coconut and Oil Palm.

The more labour intensive operations, such as pumping of irrigation water, land preparation and threshing are the first operations, which are to be mechanized. Large amount labour or draft power, which can be replaced through machines, provides a strong incentive to mechanize. Studies on efficiency of farm mechanization revealed that if the mechanization used properly a farmer can save seeds $15-20$ per cent, fertilizer $20-30 \%$ per cent, time 20-30 per cent, laboures 5-20 per cent, and increase in cropping intensity 1015 per cent, higher productivity $15-20$ per cent (Surendra Singh., 2008).

The present study was conducted in 5 villages of Koppal district by involving 150 farmers. The main objective of the present study was to analyze the extent of knowledge possessed and adopted by the farmers about farm mechanization practices. This investigation will give an idea about extent of level farm mechanization in Koppal district of Karnataka state this will facilitate to take appropriate decisions and actions by State Departments, policy makers, professionals, administrators and technocrats in their attempt to improve farm mechanization and ensure thrust on food processing industries creating a value chain of industries across the produce in the region.

\section{Materials and Methods}

Present research work was conducted in Koppal district; Karnataka. The five RSK were randomly selected and in each randomly selected RSK one village was taken for the present study in each village 30 respondents were selected by making a sample size of 150 . For collecting data, a pretested scheduled questionnaire was prepared and by taking personal interview from each respondent the data were collected, tabulated and analyzed.

\section{Results and Discussion}

\section{Overall knowledge level of farmers on farm implements}

Result shows that, 41.33 percent of the respondents had medium level, 30.67 percent had low level and 28 percent had high level of knowledge on farm implements this was mainly due to that farmers of this region were not much aware of new improved farm implements and mechanization is slowly increasing in these areas. More than 80 percent were had knowledge on rotavators (88\%), M.B plough (87.33\%), cultivator $(83.33 \%)$ and blade harrow $(80.00 \%)$. Whereas more than 40 percent of farmers had knowledge on combine harvester (45.33\%), power weeder $(43.33 \%)$, leveler $(30.67 \%)$, fertilizer drill (30\%), seed cum fertilizer drill $(28 \%)$ and least knowledge level was absorbed in Paddy transplanter (26.67\%), and Hoes $(13.33 \%)$ this was mainly due to that paddy 
transplanting was done by manually and there was lack of awareness with respect to hoes and also which was not locally available (Table 1 and 2).

\section{Dependent on Animal Drawn Implements by Farmers}

Table 3 shows that, more than 80 percent of the farmers are doing sowing (86.67\%) and weeding $(83.33 \%)$ by animal drawn implements, more than 50 percent of the farmers are doing ploughing by indigenous plough whereas more than $45 \%$ of the farmers are using animal drawn cultivators $(45.33 \%)$, Blade Harrow (34.67), pudler (23.33\%) this was mainly due to high cost, lack of awareness and non-availability of subsidy facilities so the farmers are still dependent on animal drawn farm implements.

Table.1 Overall knowledge level of the respondents about farm implements

$$
(\mathrm{n}=150)
$$

\begin{tabular}{|l|c|c|}
\hline Category & Frequency & percentage \\
\hline low (Mean - 0.425*SD) & 46 & 30.67 \\
\hline Medium(Mean $\pm \mathbf{0 . 4 2 5} *$ SD) & 62 & 41.33 \\
\hline High (Mean + 0.425*SD) & 42 & 28.00 \\
\hline
\end{tabular}

Source: Primary data

Table.2 Knowledge level of the respondents about farm implements

$(\mathrm{n}=150)$

\begin{tabular}{|c|l|c|c|}
\hline SI. No. & \multicolumn{1}{|c|}{ Implements } & Frequency & Percentage \\
\hline $\mathbf{1}$ & Cultivator & 125 & 83.33 \\
\hline $\mathbf{2}$ & M.B. Plough & 96 & 87.33 \\
\hline $\mathbf{3}$ & Disc Harrow & 132 & 84.00 \\
\hline $\mathbf{4}$ & Rotavator & 42 & 28.00 \\
\hline $\mathbf{5}$ & Seedcum Fertilizer Drill & 45 & 30.00 \\
\hline $\mathbf{6}$ & fertilizer drill & 65 & 43.33 \\
\hline $\mathbf{7}$ & Power Weeder & 20 & 13.33 \\
\hline $\mathbf{8}$ & Hoes & 89 & 59.33 \\
\hline $\mathbf{9}$ & Sprayer & 96 & 64.00 \\
\hline $\mathbf{1 0}$ & Threshers & 68 & 45.33 \\
\hline $\mathbf{1 1}$ & Combine Harvester & 40 & 26.67 \\
\hline $\mathbf{1 2}$ & Paddy Transplanter & 102 & 68.00 \\
\hline $\mathbf{1 3}$ & Pudler & 120 & 80.00 \\
\hline $\mathbf{1 4}$ & Blade Harrow & 46 & 30.67 \\
\hline $\mathbf{1 5}$ & leveller & & \\
\hline $\mathbf{4}$
\end{tabular}

Source: Primary data 
Table.3 Dependent on Animal Drawn Implements by Farmers

$(\mathrm{n}=150)$

\begin{tabular}{|c|l|r|r|}
\hline Sl. No. & \multicolumn{1}{|c|}{ Implements } & Frequency & Percentage \\
\hline $\mathbf{1}$ & Indigenous plough & 75 & 50.00 \\
\hline $\mathbf{2}$ & Blade harrow & 52 & 34.67 \\
\hline $\mathbf{3}$ & Cage wheel & 65 & 43.33 \\
\hline $\mathbf{4}$ & Seed drill & 130 & 86.67 \\
\hline $\mathbf{5}$ & Weeder & 125 & 83.33 \\
\hline $\mathbf{6}$ & Pudler & 35 & 23.33 \\
\hline $\mathbf{7}$ & Cultivator & 68 & 45.33 \\
\hline
\end{tabular}

Source: Primary data

Table.4 Adoption tractor drawn implements by farmers

$(\mathrm{n}=150)$

\begin{tabular}{|c|l|c|c|}
\hline SI. No. & \multicolumn{1}{|c|}{ Implements } & Frequency & Percentage \\
\hline $\mathbf{1}$ & Cultivator & 109 & 72.67 \\
\hline $\mathbf{2}$ & M.B. Plough & 25 & 82.67 \\
\hline $\mathbf{3}$ & Disc Harrow & 96 & 64.00 \\
\hline $\mathbf{4}$ & Rotavator & 10 & 6.67 \\
\hline $\mathbf{5}$ & Seed cum Fertilizer Drill & 12 & 8.00 \\
\hline $\mathbf{6}$ & fertilizer drill & 45 & 30.00 \\
\hline $\mathbf{7}$ & Power Weeder & 5 & 3.33 \\
\hline $\mathbf{8}$ & Hoes & 125 & 83.33 \\
\hline $\mathbf{9}$ & Sprayer & 82 & 54.67 \\
\hline $\mathbf{1 0}$ & Threshers & 56 & 37.33 \\
\hline $\mathbf{1 1}$ & Combine Harvester & 2 & 1.33 \\
\hline $\mathbf{1 2}$ & Paddy Transplanter & 87 & 58.00 \\
\hline $\mathbf{1 3}$ & Pudler & 92 & 61.33 \\
\hline $\mathbf{1 4}$ & Blade Harrow & 65 & 43.33 \\
\hline $\mathbf{1 5}$ & leveller & & \\
\hline
\end{tabular}

Source: Primary data

Table.5 Overall adoption tractor drawn implements by farmers

$(n=150)$

\begin{tabular}{|l|c|c|}
\hline \multicolumn{1}{|c|}{ Category } & Frequency & percentage \\
\hline low (Mean - 0.425*SD) & 57 & 38.00 \\
\hline Medium(Mean $\mathbf{\pm 0 . 4 2 5 * S D )}$ & 68 & 45.33 \\
\hline High (Mean + 0.425*SD) & 25 & 16.67 \\
\hline
\end{tabular}

Source: Primary data 
Table.6 Factors responsible for non-adoption of farm implements

$$
(\mathrm{n}=150)
$$

\begin{tabular}{|l|l|l|l|}
\hline SI. No & \multicolumn{1}{|c|}{ Factors } & Frequency & Percentage \\
\hline A & Rotavator & 68 & 45.33 \\
\hline & $\begin{array}{l}\text { Cost of Rotavator (> 60,000) } \\
\text { Maintance and repair }\end{array}$ & 46 & 30.67 \\
\hline Combine Harvester & 120 & 80.00 \\
\hline & $\begin{array}{l}\text { Cost is high (> 6 lakhs) } \\
\text { required skill for operation }\end{array}$ & 116 & 77.33 \\
\hline & Maintance and repair cost & & \\
\hline Paddy transplanter & 126 & 84.00 \\
\hline & $\begin{array}{l}\text { Cost is high (> 4 lakhs) } \\
\text { Uniform seedlings were not raised }\end{array}$ & 86 & 57.33 \\
\hline & required skill for operation & 76 & 50.67 \\
\hline Does & & \\
\hline & Lack of awareness & 139 & 92.67 \\
\hline non availability of the equipment in the local area & 145 & 96.67 \\
\hline E & Seed cum fertilizer drill & & \\
\hline & Cost & 96 & 64.00 \\
\hline & Lack of awareness & 89 & 59.33 \\
\hline Fertilizer drill & & \\
\hline & Cost & 93 & 62.00 \\
\hline & Lack of awareness & 62 & 41.33 \\
\hline
\end{tabular}

Source: Primary data

Adoption tractor drawn implements by farmers

Table 5 shows that, 45.33 percent farmer category belongs medium level of adoption, 38 percent of farmers category belongs to low level of adoption whereas 16.67 percent belongs to high level of adoption category.

The overall adoption of tractor drawn implements was presented in table 4 more than 80 percent of the farmers are adopted sprayers (83.33\%), M.B. plough (82.67\%), more than 60 percent of the farmers are using cultivators (72.67\%), Rotavators (64\%), Blade harrow (61.33\%), respectively. These were mainly due to fact that, constraints faced by framers like, drudgery involved in farm operations, scarcity of labours, it became necessary to the farmers adopt farm mechanization practices. These findings are in confirmatory with (Sahana et al., 2017).

Whereas least percentage of adoption was found in paddy transplanter $(1.33 \%)$, Hoes $(3.33 \%)$, Seed cum fertilizer drill (6.67\%), Fertilizer drill (8\%), respectively.

This was mainly due to the cost of paddy transplanter was high and Seedlings were exposed to possible injury during handling and Plants tend to grow more slowly than direct seeding, with respect to Hoes and seed cum fertilizer drill lack of awareness, high cost and also there is no uniform seed are sown during operation. 


\section{Factors responsible for non-adoption of farm} implements

Table 6 shows that, the significant proportion of farmers opined that cost of rotavators (>60,000), combine harvester (> 6 lakhs), paddy transplanter (> 4 lakhs) was high and more than 50 percent of the farmer opined that, required skill labour for operation of combine harvester, paddy transplanter and uniform seedling were not raised the paddy transplanter more than 90 percent of the farmer opined that, maintenance and repair cost for combine harvester was high. More than 92 percent of farmers have lack of awareness of hoes and opined that there was non-availability of this equipment in local areas.

Even though more than 40 percent farmers had medium level of knowledge on farm implements still farmers are lacking in adopting mechanization and least percentage of adoption was found in paddy transplanter $(1.33 \%)$, Hoes $(3.33 \%)$, Seed cum fertilizer drill (6.67\%), Fertilizer drill (8\%), respectively.

This was mainly due to lack of awareness, high cost and farmers are not much exposed to improved farm machineries.

So, there is a more scope for developing departments, state agriculture departments for introducing more schemes on farm machineries, Agro industries corporations, private machine owners, co-operative societies for introducing of custom hiring centers so the farmers can use the machines on payment basis and for conducting of farm machinery exhibition to encourage the farmers to know about the importance of farm mechanization.

\section{Acknowledgement}

Author is thankful to University of Horticultural Sciences, Bagalkot, Karnataka, India for providing financial support to carry out present work successfully.

\section{References}

Anonymous, 2014. Report on state of Indian Agriculture, Department of Agriculture and Cooperation, Directorate of Economics and Statistics, New Delhi.

Mehta, C. R., Chandel, N. S., Senthilkumar, T., and Kanchan Singh, K. 2014.Trends of Agricultural Mechanization in India. CSAM Policy Brief Issue No.2, June.

Nagaraj, P.S., Dhananjaya Swamy, A., Madhushree, and Vidyadhara, B. 2013. A Study on Knowledge and Adoption of Farm Mechanization by Paddy Grower in Tungabhadra Project Area, Karnataka. International Journal of Agriculture and Food Science Technology. 4(4): 385-390.

Sahana, S., Shashikiran, Kulkarni Neha, P., and Arunkumar, P. 2017. Adoption and attitude of the farmers on mechanization of paady in command areas of Karnataka. International Journal of Agriculture Sciences. 9 (29): 4382-4384.

Sahay, C.S., Satapathy, K.K., Agarwal, and Mishra A.K. 2002. Evaluation of selfpropelled rice transplanter in valley and terraced lands of north eastern hilly region. Agricultural Engineering Today. 26 (5): 1-10.

Verma, S. R. 2008. Impact of Agricultural Mechanization on production, productivity, cropping intensity income generation and employment of labour. College of Agril. Engg. Punjab Agric. Univ., Ludhiana.

\section{How to cite this article:}

Shoba, H., N. Rajeshwari and Yogeeshappa, H. 2018. A Study on Farm Mechanization Level of Farmers in North Karnataka. Int.J.Curr.Microbiol.App.Sci. 7(02): 652-657.

doi: https://doi.org/10.20546/ijcmas.2018.702.080 